\title{
High IQ Students' Thinking Profile in Making External Mathematical Connections Seen from Gender Difference
}

\author{
Karim Karim \\ Lambung Mangkurat University \\ Banjarmasin, Indonesia \\ karim_fkip@unlam.ac.id
}

\author{
I Ketut Budayasa \\ Universitas Negeri Surabaya \\ Surabaya, Indonesia \\ ketutbudayasa@yahoo.com
}

\author{
Tatag Yuli Eko Siswono \\ Universitas Negeri Surabaya \\ Surabaya, Indonesia \\ tatagsiswono@unesa.ac.id
}

\begin{abstract}
The research aims to know thinking profile of high IQ students in making external mathematical connections seen from gender difference.The research method employed was qualitative explorative research. The research subject consisted of 2 students of the senior high school in XII grade who had high IQ (a male and a female student).Data were collected through interview and analyze to the reduction of data, data display, and conclusion drawing/verification. The result showed that high IQ male student (MS) and high IQ female student (FS) received information by doing attention and rehearsal, and recalled the information by doing recognition. MS processing information by using linkages between mathematics concepts and principles with physics subject and with some problems in his real life.While FS processing information by using linkages between mathematics concepts and principles with physics subject, and geography subject, as well as some problems in her real life. The implications of this research result are that in learning mathematics, students need to be learned to be able to managethe information they have, so they can create external mathematical connections.
\end{abstract} gender

Keywords-external mathematical connections; thinking;

\section{INTRODUCTION}

The term "mathematical connections" was popularized by NCTM in 1989 and set as one of the mathematic learning standards in the United States [1]. In Indonesia, the importance of mathematical connections on mathematics subject can be found on KTSP and 2013 curriculum [2][3]. Mathematical connections can be divided into three aspects: (1) connections among mathematical concepts and principles, (2) connections between mathematics and other subjects, (3) connections between mathematics and students' real life [1][4][5] Mathematical connections with other subjects and the real life of students are called as external mathematical connections. External mathematical connections are important to teach to the students so they can understand the benefits of learning mathematics. In order to be able to make mathematical connections, the process of thinking is required.[6]stated that thinking is a process to manage and transform information into memory. The statement by [6] is in line with the cognitive psychology view about thinking which is believed as the thinking process that uses information processing theory. Thinking according to this theory sees the thinking process is started by receiving information, processing information, saving information, and recalling information from memory [6][7][8][9].

Several characteristics of students who is focused on the research in the education sector are IQ and gender [6][9]. The research done by [10]found out that there is a significant positive correlation between IQ and the learning achievement of the students. Meanwhile, [11]reported the result of the differences of capability between male and female students in resolving mathematical problems. The differences were spotted on spatial, verbal, and quantitative capability. [12]stated that the mathematical connections capability on senior high school students, both internal and external mathematical connections, is still low. This will impact on the low capability of the students to solve the mathematical problem. This problem needs to be studied further to know the thinking process of students in making external mathematical connections. IQ and gender are connected in order to also uphold individual differences.

The aim of this research is to understand the thinking profiles of high IQ male and female students in making external mathematical connections. The type of this research is explorative with the qualitative approach with the subjects of 1 high IQ male student and 1 high IQ female student. The subjects are focused on high IQ students because high IQ students have potential to make good external mathematical connections. The description of high IQ students in making external mathematical connections can be used to understand other students in making external mathematical connections who have IQ below them. The implication of this research is the students in studying mathematics need to be taught and trained to process and recall information so they can use mathematics in other subjects and can solve problems in real life context. 


\section{METHOD}

The type of this research is explorative with the qualitative approach. Explorative research is used to reveal high IQ students' thinking profile in making external mathematical connections. The subject of this research isthe students of XII grade in State high school 1 Banjarmasin which consists of 1 high IQ male student 1 high IQ female student who have relatively similar mathematics capability and IQ level. The researcher is helped by a psychology to measure the IQ level. It found that the IQ of both subjects is 123 (superior).

The instruments used in this research consists of the researcher as the main instrument, the examining sheet of mathematical problems, and interview guidelines. Data analytical procedures used in this research is analytical procedures and model field [13] consist of data reduction, data display, and conclusion drawing/verification. The mathematical problem which becomes the stimulus in order for subjects to make external mathematical connections is:

"Ishmat's height is $170 \mathrm{~cm}$. He is a member of the color hoister team of State high school 1 Banjarmasin. After practice, he stands in the corner of the schoolyard while seeing at the flying flag on flagpole on the schoolyard. When standing upright, he sees the topmost of the flagpole with elevation degree of $15^{\circ}$. Moments later, he walks to the flagpole for $29,5 \mathrm{~m}$ and sees the topmost of the flagpole with elevation degree of $45^{\circ}$. Determine the height of the flagpole!"

The data result will be explained based on the thinking steps according to the information processing theory: (1) receiving information, (2) processing information, (3) saving information, (4) recalling information.

\section{RESULTS AND DISCUSSION}

\subsection{Thinking profileof high IQ male student}

External mathematical connections made by the male student (MS) consists of mathematical connections with physics subjectand real-life context. Regarding the connections with physicssubject, he used parabolic motions, work, equilibrium, the center of gravity, and torque. For real-life context, he made the connections by calculating the tree's height, distance from the height, the wide of the yard, and the wide of the wall that will be painted.Mathematical connections scheme was madeby MS can be seen in figure 1 .

According to mathematical connections made by MS with physics subject and real-life context, thus the conclusion drawing thinking profile MS in making external mathematical connections is as follows:

1. Receiving information with attention and rehearsal, then continued with recognizing mathematical principles and concepts on the mathematical problem.

2. Processing information with the strategy of making sketch then continued by recognizing and using the relation among mathematical concepts and principles on the mathematical problem-solving. After that, he made the connections with physics subjectand real-life context.
Regarding the connections with physicssubject, he used parabolic motions, work, equilibrium, the center of gravity, and torque. For real-life context, he made the connections by calculating the tree's height, distance from the height, the wide of the yard, and the wide of the wall that will be painted. Mathematical concepts and principles used by MS in making connections with physics subject and real-life context are very variative.

3. Saving information by defending received information and existing knowledge in the memory. Later, connecting it with the example of mathematical external connections with physics subject and real-life context.

4. Recalling information by recognition from semantic memory. Recognition happened when recalling the name of subjects in mathematics that have relation with real-life context and physicssubject that have connections with the problems he made. The subjects in physics connected with mathematical concepts and principles are materials of the $\mathrm{X}$ grade first semester until XII grade second semester. Meanwhile, for real-life context, MS recalled mathematical concepts and principles he learned from IX grade of junior high school until XII grade of senior high school.

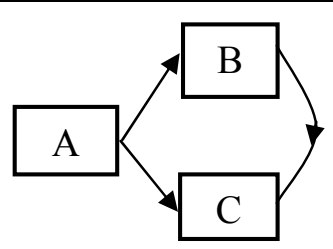

Notes:

A: Mathematical problems.

B: Mathematical connections with physicssubject.

$\mathrm{C}$ : Mathematical connections with real-life context.

Fig. 1. Mathematical Connections Scheme was Made by MS

\subsection{Thinking profile of high IQ female student}

External mathematical connections made by the female student (FS) consists of mathematical connections with physicssubject, geographysubject, and real-life context. Regarding the connections with physicssubject, she used acceleration, thrust, work, circular motion, and stability problem. Meanwhile, for the connections with geographysubject, she used the problem of calculating the depth of the sea and the distance of planets. For real-life context, she made the connections by the problem of reading distance, the slope of the stairs, measuring the tree's height, and playing kites.Mathematical connections scheme was made by FS can be seen in figure 2 .

According to mathematical connections made by FS with physics, geography, and real-life context, thus the conclusion drawing thinking profile FS in making mathematical external connections is as follows: 
1. Receiving information with attention and rehearsal, then continued with recognizing mathematical principles and concepts on the mathematical problem.

2. Processing information with the strategy of making sketch then continued by recognizing and using the relation among mathematical concepts and principles on the mathematical problem solving. After that, she made the connections with physicssubject, geographysubject, and real-life context. Regarding to the connections with physics, she used acceleration, thrust, work, circular motion, and stability problem. Meanwhile, for geographysubject, she used the problem of calculating the depth of the sea and the distance of planets. For real-life context problems. she usedthe problem of reading distance, the slope of the stairs, measuring the tree's height, and playing kites. Mathematical concepts and principles used by FS to make connections with physics subject are very variative, but for real-life context, she only used distance concepts, angles,right triangle, and Pythagoras Theorem.

3. Saving information by defending received information and existing knowledge in memory. Later, connecting it with the example of external mathematical connections with physics, geography, and real-life context.

4. Recalling information by recognition from semantic memory. Recognition happened when recalling the name of subjects in mathematics that have relation with real-life context and subjects in physics and geography that have connections with the problems he made. The subjects in physics connected with mathematical concepts and principles are materials of the $\mathrm{X}$ grade first semester until XII grade second semester. For geography subject, she used materials from $\mathrm{X}$ grade of senior high school. Meanwhile, for real-life context, FS recalled mathematical concepts and principles she learned from VII grade of junior high school until XI grade senior high school, especially those which have relation to geometric principles and concepts.

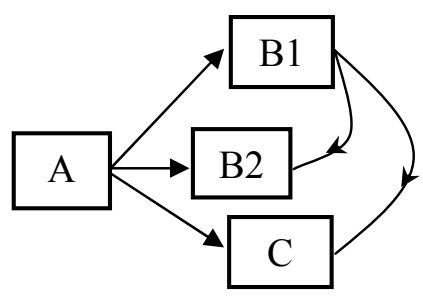

Notes:

A: Mathematical problems.

B1: Mathematical connections with physicssubject.

B2: Mathematical connections with geographysubject.

C: Mathematical connections with real-life context.

Fig. 2. Mathematical Connections Scheme was Made by FS

External mathematical connections made by MS and FS with other subjects and real-life context are very variative. The result of this research is in line with the statement by [14]who said that high IQ students have a deeper understanding of the material so it can increase their memory achievement. Memory achievement is really needed in making externalmathematical connections. It also supports the idea of $[15][16]$ who stated that mathematics subject in schools, students need to be pushed to connect the materials that they have learned in their solving the real-life problems.

External mathematical connections made by MS and FS are different, but their thinking profiles in making mathematical external connections is relatively the same. The thinking process of $\mathrm{MS}$ and $\mathrm{FS}$ in receiving and saving information are relatively the same. However, in processing and recalling information stage there are differences in making external mathematical connections examples and recalling used mathematical concepts and principles. The differences are caused by the gender difference. This is in line with the statement by [17] who said that the factors that can influence particular capability between male and female students are psychological development, physical development, and brain development. The differences in processing information also influenced by existing knowledge and past experiences. This is explained by [9] that in processing information is highly influenced by the mind, past experiences, existing knowledge, and motivation.

The variation of external mathematical connections made by MS and FS when processing information shows that high IQ students have good capability to remember and processing information. More variation the external mathematical concepts students use means that the students already master many mathematical concepts and principles that he/she can use in solving problems on other subjects or in real-life. This is in line with the statement by [18]who stated that mathematical connections as a tool to solve mathematical problems.

\section{IV.CONCLUSION}

Based on the results above it can be concluded that MS and FS received information by doing attention and rehearsal, and recalled the information by doing recognition. MS processing information by using linkages between mathematics concepts and principles with physics subject and with some problems in his real life.Regarding the connectionswith physics subject, he used parabolic motions, work, equilibrium, the center of gravity, and torque. For reallife context, he made the connections by calculating the tree's height, distance from a height, the wide of the yard, and the wide of the wall that will be painted.

While FS processing information by using linkages between mathematics concepts and principles with physics subject, and geography subject, as well as some problems in her real life. Regarding the connections with physicssubject, she used acceleration, thrust, work, circular motion, and stability problem. Meanwhile, for geographysubject, she used the problem of calculating the depth of the sea and the distance of planets. For real-life context problems.she usedthe 
problem of reading distance, the slope of the stairs, measuring the tree's height, and playing kites.

\section{REFERENCES}

[1] NCTM, Curriculum and Evaluation Standards for School Mathematics. Reston: VA: Arthur, 1989.

[2] Depdiknas, Peraturan-Peraturan Menteri Pendidikan Nasional, No. 22, 23, dan 24 Tahun 2006. Tentang Standar Isi untuk Pendidikan Dasar dan Menengah. Jakarta: Depdiknas, 2006.

[3] Kemendikbud, Peraturan Menteri Pendidikan dan Kebudyaan No. 59 Tahun 2014. Tentang Kurikulum 2013 Sekolah Menengah Atas/Madrasah Aliyah. Jakarta: Kemendikbud, 2014.

[4] NCTM, No Tprinciples and Standards for School Mathematicsitle. Reston: VA: Arthur, 2000.

[5] M. Judith, "An Aspect of Mathematical Understanding: The Notion of Connected Knowing. Proceeding of the 28th Conference of The International Group for The Psychology of Mathematics Education,’2004.[Online].Available:https://www.emis.de/proceedin gs/ PME28/ RR/RR301 Mousley.pdf.

[6] S. John W, Psikologi Pendidika. Penerjemah Tri Wibowo, B. S., Kedua. Jakarta: Kencana, 2010.

[7] M. Yansen, Proses Berpikir Siswa dalam Pembentukan Konsep Algoritma Matematis Makalah. Makalah Pidato Dies Natalies XXXI IKIP Sanata Dharma Salatiga. Yogyakarta, 1986.

[8] S. Robert L, Cognitive Psychology. Sixth Edition. Boston: Allyn and Bacon, Inc., 2001.

[9] S. Robert E, Psikologi Pendidikan, Teori dan Praktik. Edisi Kesembilan. Penerjemah Marianto Samosir. Jakarta: PT. Indeks, 2011.

[10] F. C. Deary IJ, Strand S, Smith P, "Intelligence and Educational Achievement. ScienceDirect, Intelligence 35.13-21." [Online]. Available: www. sciencedirect.com.

[11] Z. Z, "Gender Differences In Mathematical Problem Solving Patterns: A Review of Literature.," Int. Educ. J., vol. 8, no. 2, pp. 187-203, 2007.

[12] Ruspiani, "Kemampuan Siswa dalam Melakukan Koneksi Matematika. Unpublished Thesis.," Pendidikan Indonesia University Bandung, 2000

[13] A. M. MILES, Matthew B.; HUBERMAN, Qualitative Data Analysis. Second Edition. SAGE Publications. International Educational and Professional Publisher, 1994.

[14] W. W.S, Psikologi Pengajaran. Yoyakarta: Media Abadi, 2009.

[15] G. De Corte, E., Lieven, V.; Brian, "Connecting Mathematics Problem Solving to The Real Word," University of Leuven, Belgium, 2000

[16] S. L. . M. Diez-P. J. R., Ksenija, "Math Is Everywhere": Connecting Mathematics To Students' Lives," J. Math. Cult., vol. VI (2), no. 1558-5336, 2006.

[17] J. Eric, Brain-Based Learning: Pembelajaran Berbasis Kemampuan Otak, Cara Baru dalam Pengajaran dan Pelatihan. Yogyakarta: Pustaka Pelajar, 2008.

[18] H. Theodore R., Connections As Problem-Solving Tools", In YearBook P.A. House (1995), Connecting Mathematics Across The Curriculum. Virginia: The National Council of Teachers of Mathematics, Inc, 1995. 